\title{
Green Bean, Pea and Mesquite Whole Pod Flours Nutritional and Functional Properties and Their Effect on Sourdough Bread
}

\author{
Angela Mariela González-Montemayor ${ }^{1}{ }^{\oplus}$, José Fernando Solanilla-Duque ${ }^{2} \mathbb{C}$, Adriana C. Flores-Gallegos ${ }^{1}{ }^{\mathbb{C}}$, \\ Claudia Magdalena López-Badillo ${ }^{1}$, Juan Alberto Ascacio-Valdés ${ }^{1}$ [D and Raúl Rodríguez-Herrera ${ }^{1, *}$ \\ 1 Food Research Department, School of Chemistry, Universidad Autónoma de Coahuila, \\ Boulevard Venustiano Carranza and José Cárdenas s/n, Republica Oriente, Saltillo CP 25280, Mexico; \\ angelagonzalez@uadec.edu.mx (A.M.G.-M.); carolinaflores@uadec.edu.mx (A.C.F.-G.); \\ cllopezb@uadec.edu.mx (C.M.L.-B.); alberto_ascaciovaldes@uadec.edu.mx (J.A.A.-V.) \\ 2 Agroindustrial Engineering Department, School of Agrarian Sciences, Universidad del Cauca, \\ Popayán 190002, Colombia; jsolanilla@unicauca.edu.co \\ * Correspondence: raul.rodriguez@uadec.edu.mx; Tel.: +52-(844)-416-9213
}

check for updates

Citation:

González-Montemayor, A.M.;

Solanilla-Duque, J.F.;

Flores-Gallegos, A.C.;

López-Badillo, C.M.;

Ascacio-Valdés, J.A.;

Rodríguez-Herrera, R. Green Bean,

Pea and Mesquite Whole Pod Flours

Nutritional and Functional Properties and Their Effect on Sourdough Bread. Foods 2021, 10, 2227. https:// doi.org/10.3390/foods10092227

Academic Editors: Antonio

José Pérez-López and

Luis Noguera-Artiaga

Received: 9 August 2021

Accepted: 13 September 2021

Published: 20 September 2021

Publisher's Note: MDPI stays neutral with regard to jurisdictional claims in published maps and institutional affiliations.

Copyright: (c) 2021 by the authors Licensee MDPI, Basel, Switzerland. This article is an open access article distributed under the terms and conditions of the Creative Commons Attribution (CC BY) license (https:// creativecommons.org/licenses/by/ $4.0 /$ )

\begin{abstract}
In this study, proximal composition, mineral analysis, polyphenolic compounds identification, and antioxidant and functional activities were determined in green bean (GBF), mesquite $(\mathrm{MF})$, and pea (PF) flours. Different mixtures of legume flour and wheat flour for bread elaboration were determined by a simplex-centroid design. After that, the proximal composition, color, specific volume, polyphenol content, antioxidant activities, and functional properties of the different breads were evaluated. While GBF and PF have a higher protein content (41-47\%), MF has a significant fiber content (19.9\%) as well as a higher polyphenol content (474.77 mg GAE/g) and antioxidant capacities. It was possible to identify $\mathrm{Ca}, \mathrm{K}$, and $\mathrm{Mg}$ and caffeic and enolic acids in the flours. The legume-wheat mixtures affected the fiber, protein content, and the physical properties of bread. Bread with MF contained more fiber; meanwhile, PF and GBF benefit the protein content. With MF, the specific bread volume only decreased by $7 \%$. These legume flours have the potential to increase the nutritional value of bakery goods.
\end{abstract}

Keywords: mesquite; legume flour; antioxidant activity; bakery product

\section{Introduction}

Currently, there is a demand for novel, tasty, and healthy baked goods; bread manufacturing fills the requirements for specific groups that demand products with functional ingredients, that are gluten-free, or that have a high fiber content [1-3]. For the improvement of bread formulations, there is a growing interest in minor cereal, ancient crops, pseudocereals, and legumes, such as oat, rice, corn, sorghum, quinoa, amaranth, buckwheat, chickpea, pea, and soybean, as ingredients for bread making applications [3].

The fortification of wheat flour products with legume flours has been recognized as a viable strategy because legumes are rich in fibers, minerals, phytochemicals, and proteins (compensating the deficiency of the amino acid of the products), and these flours are known for their functionality (water-binding capacity, fat absorption) [4]. Among the legumes used to fortify bread, pea (Pisum sativum) is the most investigated.

In bread, there are reports about the inclusion of germinated pea flour [5] and fermented pea flour [6]. The obtained products were of good quality and had high protein and fiber content as well as a higher water absorption capacity along with achieving gluten-free quality products.

Other legumes successfully added into bread are beans (Phaseolus vulgaris) and mesquite (Prosopis spp.), also known as algarrobo. Regarding beans in an immature form, known as a green bean, no reports of its addition in bakery products are reported. However, white kidney beans $[7,8]$ have been successfully added to bread. Using white 
kidney beans, it was possible to obtain bread with a higher protein, fiber, and ash content that also had acceptable sensory (texture and flavor) characteristics and oil and water absorption changes. In mesquite flour, it is documented that it is possible to develop bakery goods such as gluten-free muffins and Panettone bread with increased nutritional values and antioxidant activities [9].

According to our knowledge, specifically, the characteristics of mesquite (Prosopis glandulosa) pod flours are limited. It is desirable to compare the effects of these legume flours on bread made with one of the most used legumes, the pea. Owing to the previous antecedents, this study aimed to characterize the obtained flours from mesquite, green bean, and pea whole pods and to incorporate these flours with whole wheat flour into sourdough bread. Sourdough was chosen for its known benefits in improving rheological and sensory qualities and for improving the shelf-life of bread [10].

\section{Materials and Methods}

\subsection{Plant Material}

Batches of $12 \mathrm{~kg}$ of whole pods of pea (Pisum sativum) and green bean (Phaseolus vulgaris) were purchased in a local market. The mesquite (Prosopis glandulosa) pods were collected in Ramos Arizpe, Coahuila, México (North latitude $25^{\circ} 35^{\prime} 04.4^{\prime \prime}$, West longitude $100^{\circ} 54^{\prime} 50.4^{\prime \prime}, 1348$ masl). All of the samples were rinsed with water and were dried at $50{ }^{\circ} \mathrm{C}$. After, the pods were ground (Moulinex, Écully, France). The flours were sieved to obtain a particle size ranging from 355 and $<75 \mu \mathrm{m}$. The pea (PF), green bean (GBF), and mesquite (MF) flours were kept at room temperature in hermetic bags and were covered from light for one week (after this time, the experiments were started).

\subsection{Flour Characterization}

\subsubsection{Proximal Composition}

The nutritional analysis of the legume flours was conducted as stated by the following Association of Official Analytical Chemists (AOAC methods) [11]: fat (AOAC 945.16), ash (AOAC 920.181), crude fiber (AOAC 962.09), and total protein (total nitrogen $* 6.25$ ) (AOAC 978.02). Then, the carbohydrates were quantified by difference.

\subsubsection{Mineral Analysis}

For this identification and quantification, $3 \mathrm{~g}$ of the different legume flours were placed in the sample cup of an X-Ray Fluorescence (XRF) Spectrometer (Epsilon 1, Malvern Panalytical, Madrid, Spain). The patterns were interpreted with the Omniam software.

\subsubsection{Extraction and Determination of Phenolic Content and Profile by RP-HPLC-ESI-MS}

For this analysis, the methodologies mentioned by Chen et al. [12] were used. The samples $(1 \mathrm{~g})$, which had been previously mixed with $80 \%$ methanol $(1: 10 \mathrm{w} / \mathrm{v})$, were placed in ultrasound equipment (Branson 5510, Marshall Scientific, Hampton, NH, USA at $25{ }^{\circ} \mathrm{C}$ for $10 \mathrm{~min}$. Later, to obtain the supernatant, the samples were centrifuged at $4000 \mathrm{~g}$ for $10 \mathrm{~min}$. The extraction and centrifugation processes were repeated twice. The supernatants were dried at $40^{\circ} \mathrm{C}$, and the obtained residues were dissolved in methanol and were stored at $-80^{\circ} \mathrm{C}$ until their use. The phenolic content was determined by mixing $395 \mu \mathrm{L}$ of distilled water with $5 \mu \mathrm{L}$ of the sample extract; then, the Folin-Ciocalteu reagent $(400 \mu \mathrm{L})$ was added. The mix was rested for $5 \mathrm{~min}$, and $\mathrm{Na}_{2} \mathrm{CO}_{3}(0.01 \mathrm{M})$ was added, and then all of the samples were mixed with water $(2.5 \mathrm{~mL})$. Absorbance was determined at $790 \mathrm{~nm}$ in a spectrophotometer (Epoch ${ }^{\mathrm{TM}}$ microplate, Biotek, Winooski, VT, USA). Gallic acid (GA) was used to prepare the standard curve (0-400 ppm). The phenolic content was expressed as GA equivalents per gram of flour.

The obtained methanolic extracts were used to determine the phenolic profile of the flours using a Varian High Performance Liquid Chromatography (HPLC) system. Reverse phase-high performance liquid chromatography analyses were performed according to the fully described methodology of Hernández-Hernández et al. [13]. 


\subsubsection{Determination of Antioxidant Activity}

The methanolic extracts (Section 2.2.3) were also used for these determinations.

The antioxidant activity was evaluated by the 2,2-diphenyl-1-picrylhydrazyl (DPPH), 2,2'-Azino-bis(3-ethylbenzothiazoline-6-sulfonic acid) diammonium salt $\left(\mathrm{ABTS}^{ \pm}\right.$), and ferric reducing antioxidant power (FRAP) methods. Trolox was used as a standard, and the obtained results were expressed as Trolox equivalents (TE) per gram of flour.

The DPPH assay was accomplished according to the methodology described by Molyneux [14] with slight modifications. Briefly, a $60 \mu \mathrm{M}$ solution was prepared with methanol and the DPPH reagent. Then, $7 \mu \mathrm{L}$ of each sample with $193 \mu \mathrm{L}$ of the DPPH methanolic solution was mixed and kept in the dark for $30 \mathrm{~min}$. The absorbance was determined at $517 \mathrm{~nm}$.

For $\mathrm{ABTS}^{ \pm}$, according to the modified methodology of Opitz et al. [15], a solution of ABTS $^{ \pm}$at a concentration of $7 \mathrm{mM}$ was prepared and mixed with $\mathrm{K}_{2} \mathrm{~S}_{2} \mathrm{O}_{8}$ at $2.45 \mathrm{mM}$ $(1: 1 \mathrm{v} / \mathrm{v})$. This $\mathrm{ABTS}^{ \pm}$solution was left to rest for $12 \mathrm{~h}$ at $37^{\circ} \mathrm{C}$. Later, the solution was diluted with methanol to reach an absorbance of $0.7 \pm 0.02$. In the microplate, $5 \mu \mathrm{L}$ of each sample were added and $95 \mu \mathrm{L}$ of $\mathrm{ABTS}^{ \pm}$solution. The solutions rested for 1 min before the reading at $734 \mathrm{~nm}$.

For the FRAP assay, the FRAP solution was obtained by mixing TPTZ (2,4,6-Tripyridyls-triazine) at $10 \mathrm{mM}, \mathrm{FeCl}_{3}(20 \mathrm{mM})$, and acetate buffer $(0.3 \mathrm{M}, \mathrm{pH}$ 3.6) in the proportions of 1:1:10 $v / v / v$. Sample solutions $(10 \mu \mathrm{L})$ were added to the microplate followed by $290 \mu \mathrm{L}$ of the FRAP solution. Later, the samples were incubated in the dark at $37^{\circ} \mathrm{C}$ for $15 \mathrm{~min}$. The absorbance was measured at $593 \mathrm{~nm}$ [12].

\subsubsection{Functional Activities}

The water absorption (WAI) and water solubility (WSI) indexes were calculated following the method reported by Kraithong et al. [16] with modifications. One gram of each flour sample was suspended in $10 \mathrm{~mL}$ of distilled water and was mixed for $1 \mathrm{~min}$. Then, the suspensions were stirred and heated in a water bath at $70{ }^{\circ} \mathrm{C}$ for $30 \mathrm{~min}$. The next step was centrifugation at $3000 \mathrm{rpm}$ for $10 \mathrm{~min}$. The supernatants were placed into an aluminum container to remove moisture at $105^{\circ} \mathrm{C}$ for $12 \mathrm{~h}$. The obtained dry solids were weighted. WAI and WSI were calculated following the equations:

$$
\begin{gathered}
\text { WAI }(\mathrm{g} / \mathrm{g})=\text { weight of wet sediment/weight of flour sample } \\
\text { WSI }(\%)=(\text { weight of dried supernant/weight of flour sample }) \times 100
\end{gathered}
$$

For the water (WHC) and oil (OHC) holding capacities, $1 \mathrm{~g}$ of each flour sample was stirred with $10 \mathrm{~mL}$ of distilled water or corn oil (Cristal, AGYDSA, Guadalajara, Jalisco, Mexico). These suspensions were centrifuged at $2200 \mathrm{~g}$ for $30 \mathrm{~min}$. The supernatant was recovered and quantified. WHC was expressed as g of held water per g of sample, and the $\mathrm{OHC}$ was expressed as $\mathrm{g}$ of oil. To determine the organic molecule absorption capacity (OMAC), $3 \mathrm{~g}$ of each sample was placed with $10 \mathrm{~mL}$ of corn oil for $24 \mathrm{~h}$ at $25^{\circ} \mathrm{C}$. Later, the samples were centrifuged at $2000 \mathrm{~g}$ for $15 \mathrm{~min}$. OMAC was expressed as the absorbed hydrophobic component and were calculated in g oil/sample g [17].

\subsection{Bread Preparation}

For bread preparation, legume flours (PF, GBF, and MF), whole wheat flour (WF) $(14 \mathrm{~g} / 100 \mathrm{~g}$ protein, $2 \mathrm{~g} / 100 \mathrm{~g}$ fat, $13 \mathrm{~g} / 100 \mathrm{~g}$ fiber, and $54 \mathrm{~g} / 100 \mathrm{~g}$ carbohydrates) provided from La Perla, Molinos del Fénix, Saltillo, Coahuila, and salt (natural fluoride iodized salt) from Sal la Fina, Mexico, were used. A type I sourdough supplied by a local bakery (Tres espigas, Saltillo, Mexico) was used as a leavening agent. Water was replaced by aguamiel (sap obtained from agave). This sap is used to obtain pulque, an alcoholic beverage with significant importance in the breadmaking industry and Mexican gastronomy [18]. The aguamiel is rich in carbohydrates (sucrose, glucose, fructose, fructooligosaccharides, and gums) and contains amino acids and phenolic compounds [19]. The primary reason 
for adding aguamiel is to improve fermentation. This sap was collected from mature Agave salmiana plants (8-10 years old) in the town of "Las Mangas" (latitude $25^{\circ} 14^{\prime} 14.9^{\prime \prime}$, longitude $101^{\circ} 10^{\prime} 16^{\prime \prime}$, altitude 1560 masl), which is located near Saltillo, Coahuila, México. This aguamiel $\left(161.5 \pm 58.68 \mathrm{~g} / \mathrm{L}\right.$ total sugars) was pasteurized at $80^{\circ} \mathrm{C}$ for $10 \mathrm{~min}$ and was kept frozen $\left(-80^{\circ} \mathrm{C}\right)$ until use.

The legume flours (PF, GBF, and MF) and the WF were mixed in the proportions of a simplex-centroid design for treatment mixtures with four different components (Table 1). The proportions of the other ingredients were: $70 \mathrm{~g}$ of aguamiel, $2.4 \mathrm{~g}$ of salt, and $20 \mathrm{~g}$ of sourdough. The first step to make bread treatments was to mix flour, salt, and aguamiel. The obtained doughs were kneaded for $10 \mathrm{~min}$ and were left to rest for $1 \mathrm{~h}$. The next step was to add the sourdough and to knead the doughs for another $1 \mathrm{~min}$, and the doughs were left to rest for $1 \mathrm{~h}$ and $20 \mathrm{~min}$. Then, the doughs were kept at $4{ }^{\circ} \mathrm{C}$ for $24 \mathrm{~h}$. Finally, the samples were baked in a convection oven (HCX Plus 3, San-Son, Naucalpan, Mexico) at $250{ }^{\circ} \mathrm{C}$ for $15 \mathrm{~min}$.

Table 1. Treatments for bread elaboration according to a simplex-centroid design with four different components.

\begin{tabular}{ccccc}
\hline Treatment & PF & GBF & Flours (g) & WF \\
\hline 1 & 10 & 10 & 0 & 80 \\
2 & 0 & 10 & 10 & 80 \\
3 & 10 & 0 & 10 & 80 \\
4 & 6.66 & 6.66 & 6.66 & 80 \\
5 & 20 & 0 & 0 & 80 \\
6 & 0 & 20 & 0 & 80 \\
7 & 0 & 0 & 20 & 80 \\
Control & 0 & 0 & 0 & 100 \\
\hline
\end{tabular}

$\overline{\mathrm{PF}}$ (pea flour), GBF (green bean flour), MF (mesquite flour), WF (whole-wheat flour).

\subsection{Bread Characterization}

The bread samples were analyzed for proximal composition with the methods described above. Bread pieces were dried at $130{ }^{\circ} \mathrm{C}$ for $1 \mathrm{~h}$ in the convection oven (AACC 44-15A) [20].

With the protein, carbohydrate, and fat composition in bread, the caloric value ( $\mathrm{kcal} / 100 \mathrm{~g})$ was calculated according to caloric coefficients in the equation [21]:

$$
\text { caloric value }(\mathrm{kcal} / 100 \mathrm{~g})=(\mathrm{g} \text { protein } \times 4)+(\mathrm{g} \text { fat } \times 9)+(\mathrm{g} \text { carbohydrates } \times 4)
$$

To measure the functional properties of WHC and $\mathrm{OHC}$, the samples were fresh The loaf volume of the samples was measured ( $24 \mathrm{~h}$ after baking) using the millet seed displacement method (AACC 10-05.01). The specific volume was calculated, dividing the loaf volume by the corresponding loaf weight. The color of the bread crumbs was determined using a Precision Colorimeter NR20XE (3NH, Shenzhen, China; the reported values are from the International Commission on Illumination, for its acronym in French the CIELab system

\subsection{Statistical Analyses}

The flour experiments were established under a randomized complete block design with three replicates. The data were analyzed using an Analysis of Variance (ANOVA). Differences among the sources of the variations were significant at $p<0.05$. When it was needed, treatment means were compared using the Tukey multiple range test. The InfoStat $/ p$ Software version $2011 p$ was used for data analysis. A simplex-centroid design for mixtures with four different components: PF, GBF, MF, and WF (Table 1) was used to evaluate the interaction in proximal components (ash, fiber, moisture, protein), color parameters $\left(\mathrm{L}^{*}, \mathrm{a}^{*}\right.$, and $\mathrm{b}^{*}$ ), loaf bread weight and volume, functional activities (WHC and 
OHC), phenol content, and antioxidant activities (by DPPH, ABTS, and FRAP methods). The experimental data were examined with the Scheffe equation:

$$
Y=\beta_{1} X_{1}+\beta_{2} X_{2}+\beta_{3} X_{3}+\beta_{12} X_{1} X_{2}+\beta_{13} X_{1} X_{3}+\beta_{23} X_{2} X_{3}+\beta_{123} X_{1} X_{2} X_{3}
$$

where $Y$ is the independent variable and where $\beta_{1}, \beta_{2}, \beta_{3}, \beta_{12}, \beta_{13}, \beta_{23}$, and $\beta_{123}$ are regression parameters, $X_{1}, X_{2}$, and $X_{3}$ are the type of flour in the mixtures. Positive values in binary coefficients indicated synergistic effects, and negative values indicated antagonism. Data were analyzed using the Statgraphic Centurion XVI. ${ }^{\circledR}$ software. Surface plots and prediction equations were obtained.

\section{Results and Discussion}

\subsection{Proximal Analysis of Flours}

The proximal analysis of PF, GBF, and MF (Table 2) showed significant moisture, ash, total fiber, protein, and carbohydrate differences. The moisture varied in a range of 5.97 to $18.71 \%$. The PF moisture was higher than those reported for pea flour $(11.22 \%)$ [22]. The reported moisture for kidney bean cultivars is between 5.43 to $11.81 \%$ [23], comparable to GBF moisture. The Prosopis chilensis showed a moisture value of $7.2 \%$, similar to MF [24]. Regarding the fat content, no significant difference was found between the legume flours. The obtained results are according to the statement that legumes contain 1-6\% lipids [25], but all of the fat values remained low, around $1 \%$.

Although the statistical analysis showed that the ash content between GBF and MF is not significantly different, it is important to notice the high value $(7.06 \%)$ of total minerals that GBF contains compared to the other flours. Even though the higher ash content increases the potential of the flour to improve mineral content in the food matrix, an ash content higher than $1 \%$ is considered to affect bread, as these molecules interfere with the functional properties of the protein [26].

There is not much information about the nutritional content of green beans. The authors reported ash values that ranged from $3-4.4 \%$ in white kidney beans $[7,8]$. Concerning MF, some of the most studied mesquite species are P. alba, P. nigra, P. pallida, $P$. chilensis, P. cineraria, P. tamarugo, and P. juliflora [9]. The range of mineral content reported in some Prosopis species is for P. alba 3.09\% [27]; meanwhile, for P. nigra and P. pallida, the ash content is $3.31 \%$ and $2.3 \%$, respectively [28,29]. In contrast, dehulled pea flour from different cultivars report ash averages of 2.6 to $3.6 \%$, similar to the ash value PF [30].

Regarding protein content, the higher values were in GBF and PF. These flours contain almost double the total protein compared to MF. Recently, Aquino-Bolaños et al. [31] determined that the protein content in P. vulgaris green beans exists in a range of 7 to $12 \%$, much lower than the values obtained in GBF; nonetheless, the protein values in white beans are $36.5-37.1 \%$ [7]. This value is close to the one obtained for GBF. The protein content of $\mathrm{PF}$ is also higher than expected. A protein content of $21.3-27.2 \%$ is reported in dehulled pea flour [30]. However, the flours from the present study were obtained including the whole pod, which may increase the protein content. In the case of PF, Mateos-Aparicio et al. [32] mentioned that the peapod contains 10\% protein. Regarding Prosopis, the protein value range is also variable between species. In P. africana dehulled flour, the protein is in the range of 23 and $25.8 \%$ [33], closer to the value obtained in MF; meanwhile, in P. alba and P. nigra, the protein concentration is about $8 \%$ [34].

Despite that, the reported fiber values are higher in the pea pod (about 58\%) [32]; in this case, the fiber is much lower in PF and GBF. The fiber values reported for white kidney beans are 15-24\% [35]. The MF presented a higher fiber value, approximately two times higher than PF and GBF. In general, most Prosopis species offer high fiber content (11 to 31\%) [9]. Concerning carbohydrates, GBF and MF had a higher content compared to PF. In red kidney beans, the reported amount of carbohydrates is 58.33\% [36], and in common dry beans, Pitura and Arnt [37] reported $60 \%$, which is higher than the value obtained for GBF $(32.95 \%)$. Similarly, the total carbohydrates reported in different pea landraces are in a 
range of 38 to $47 \%$ [38], which is also higher than PF. The carbohydrates in MF (41.79\%) are similar to those reported for P. pallida (57.6\%) [39] and P. africana (46.12\%) [40].

The PF and GBF benefits are the high protein content, but GBF has important mineral content. Although the protein content of legumes is one of the foremost studied components, in MF, the fiber content attracts attention.

Table 2. Proximal composition, mineral content, and antioxidant and functional activities of the three legume flours.

\begin{tabular}{lccc}
\hline Proximal Composition (g/100 g) & PF & GBF & MF \\
\hline Moisture & $18.71 \pm 1.35^{\mathrm{a} *}$ & $10.86 \pm 0.05^{\mathrm{b}}$ & $5.97 \pm 0.85^{\mathrm{c}}$ \\
Fat & $1.57 \pm 0.24^{\mathrm{a}}$ & $1.76 \pm 0.25^{\mathrm{a}}$ & $1.85 \pm 0.38^{\mathrm{a}}$ \\
Ash & $3.44 \pm 1.25^{\mathrm{b}}$ & $7.06 \pm 0.19^{\mathrm{a}}$ & $5.52 \pm 0.33^{\mathrm{a}}$ \\
Total fiber & $9.37 \pm 3.43^{\mathrm{b}}$ & $6.06 \pm 1.95^{\mathrm{b}}$ & $19.97 \pm 0.11^{\mathrm{a}}$ \\
Protein & $47.5 \pm 2.44^{\mathrm{a}}$ & $41.31 \pm 2.52^{\mathrm{a}}$ & $24.71 \pm 5.05^{\mathrm{b}}$ \\
Carbohydrates & $19.41 \pm 6.09^{\mathrm{b}}$ & $32.95 \pm 3.20^{\mathrm{a}}$ & $41.79 \pm 5.43^{\mathrm{a}}$ \\
Total Polyphenols (mg GA eq/g) & $65.83 \pm 1.17^{\mathrm{b}}$ & $66.34 \pm 2.51^{\mathrm{b}}$ & $474.77 \pm 31.40^{\mathrm{a}}$ \\
\hline Mineral content (mg/100 g flour) & & & \\
\hline Potassium & $1839.22 \pm 17.04^{\mathrm{c}}$ & $4400.12 \pm 0.99^{\mathrm{a}}$ & $2870.13 \pm 21.39^{\mathrm{b}}$ \\
Calcium & $1180.29 \pm 35.79^{\mathrm{b}}$ & $1880.67 \pm 7.48^{\mathrm{a}}$ & $1132.86 \pm 15.34^{\mathrm{b}}$ \\
Magnesium & $\mathrm{n} . \mathrm{d}$. & $\mathrm{n} . \mathrm{d}$. & $765.71 \pm 39.56^{\mathrm{a}}$ \\
Phosphorus & $128.45 \pm 2.43^{\mathrm{b}}$ & $223.75 \pm 9.98^{\mathrm{a}}$ & $243.25 \pm 0.80^{\mathrm{a}}$ \\
Iron & $26.34 \pm 0.24^{\mathrm{b}}$ & $39.17 \pm 0.49^{\mathrm{a}}$ & $23.13 \pm 2.82^{\mathrm{b}}$ \\
\hline Antioxidant activity (mg TE/g) & & & \\
\hline DPPH & $21.12 \pm 6.06^{\mathrm{b}}$ & $10.72 \pm 1.25^{\mathrm{b}}$ & $204.67 \pm 3.79^{\mathrm{a}}$ \\
ABTS & $9.94 \pm 7.94^{\mathrm{b}}$ & $9.64 \pm 2.73^{\mathrm{b}}$ & $95.86 \pm 0.74^{\mathrm{a}}$ \\
FRAP & $20.01 \pm 14.17^{\mathrm{b}}$ & $8.46 \pm 1.42^{\mathrm{b}}$ & $1054.19 \pm 64.42^{\mathrm{a}}$ \\
\hline Functional properties & & & \\
\hline WAI (g/g) & $4.41 \pm 0.11^{\mathrm{b}}$ & $7.11 \pm 0.13^{\mathrm{a}}$ & $2.28 \pm 0.12^{\mathrm{c}}$ \\
WSI (\%) & $73.66 \pm 0.64^{\mathrm{b}}$ & $80.61 \pm 3.53^{\mathrm{a}}$ & $64.87 \pm 1.21^{\mathrm{c}}$ \\
WHC (g water/g sample) & $3.80 \pm 0.00^{\mathrm{b}}$ & $5.77 \pm 0.15^{\mathrm{a}}$ & $2.07 \pm 0.12^{\mathrm{c}}$ \\
OHC (g oil/g sample) & $1.94 \pm 0.20^{\mathrm{a}}$ & $2.52 \pm 0.56^{\mathrm{a}}$ & $1.86 \pm 0.18^{\mathrm{a}}$ \\
OMAC (g oil/g sample) & $1.60 \pm 0.10^{\mathrm{a}}$ & $2.03 \pm 0.35^{\mathrm{a}}$ & $1.66 \pm 0.10^{\mathrm{a}}$ \\
\hline PF (pea flour),GBF (give & & & \\
\hline
\end{tabular}

$\overline{\mathrm{PF}}$ (pea flour), GBF (green bean flour), MF (mesquite flour), n.d. (not detected), WHC (water holding capacity), OHC (oil holding capacity), WAI (water absorption index), WSI (water solubility index), OMAC (organic molecule absorption capacity). ${ }^{*}$ Means with a different upper letter $\left({ }^{a, b, c}\right)$ in the same line are significantly different at $p<0.05$ according to the Tukey multiple range test.

\subsection{Mineral Content}

Through the XRF analysis, at least 47 minerals were detected from the evaluated flour samples. The more abundant minerals are presented in Table 2. In general, the flours mainly contain potassium and calcium. The third most abundant mineral was magnesium, but it was only found in MF. Other essential minerals found in the samples were sulfur, chloride, manganese, copper, and zinc.

$\mathrm{Ca}, \mathrm{Fe}, \mathrm{Zn}, \mathrm{K}, \mathrm{Na}$, and $\mathrm{Mg}$ have been reported in pea [32]. However, neither Na nor Mg were found in PF. In P. alba, P. juliflora, P. Africana, and P. pallida a wide range of minerals are reported, mainly Ca (8-1274 ppm), Fe (5.6-450), Na (5-95 ppm), K (226-460 ppm), and traces of $\mathrm{P}$ and $\mathrm{Zn}$ [9]. In comparison, $\mathrm{MF}$ contains higher amounts of $\mathrm{Mg}$ and $\mathrm{Fe}$.

GBF has significantly more Ca, K, and Fe than black bean flour (137.7, 149.12, and $6.5 \mathrm{mg} / 100$ of $\mathrm{Ca}, \mathrm{K}$, and $\mathrm{Fe}$ ) [41].

\subsection{Polyphenol Profile and Antioxidant Activity}

The RP-HPLC-ESI-MS analysis made it possible to identify 18 different compounds among the three flour samples (Table 3). The 3, 4-DHPEA-EA, and caffeic acid 4-Oglucoside compounds were identified in all of the flour samples. Secoisolariciresinol was 
only identified in PF and GBF. There are reports of quercetin, kaempferol, p-hydroxybenzoic, vanillic acid, gallic acid, ferulic acid, p-coumaric, and caffeic acid in conventional bean seeds [42]. However, quercetin and caffeic acid were only present in GBF.

Table 3. Phenolic compounds identified in the three legumes flour samples.

\begin{tabular}{|c|c|c|c|c|}
\hline Sample & $\begin{array}{l}\text { Retention Time } \\
\text { (min) }\end{array}$ & $\begin{array}{c}\text { Molecular Mass } \\
{[\mathrm{M}-\mathrm{H}]^{-1}}\end{array}$ & Compound & Family \\
\hline \multirow{8}{*}{$\mathrm{PF}$} & 3.727 & 377.1 & 3,4-DHPEA-EA & Tyrosols \\
\hline & 4.951 & 341.0 & Caffeic acid 4-O-glucoside & \\
\hline & 13.681 & 326.1 & p-Coumaroyl tyrosine & Hydroxycinnamic acids \\
\hline & 14.802 & 315.0 & Protocatechuic acid 4-O-glucoside & \\
\hline & 16.891 & 365.0 & Secoisolariciresinol (possibility) & Lignans \\
\hline & 19.521 & 395.1 & Unknown & \\
\hline & 29.634 & 787.0 & $\begin{array}{l}\text { Patuletin 3-O-glucosyl- }(1 \rightarrow 6) \text { - } \\
\text { [apiosyl }(1 \rightarrow 2) \text { ]-glucoside }\end{array}$ & Methoxyflavonols \\
\hline & 34.429 & 933.0 & Pedunculagin III & Ellagitannins \\
\hline \multirow{6}{*}{ GBF } & 3.709 & 377.1 & 3,4-DHPEA-EA & Tyrosols \\
\hline & 4.520 & 341.0 & Caffeic acid 4-O-glucoside & \\
\hline & 15.147 & 315.0 & Protocatechuic acid 4-O-glucoside & Hydroxycinnamic acids \\
\hline & 16.605 & 365.0 & Secoisolariciresinol (possibility) & \\
\hline & 25.760 & 378.0 & Medioresinol & Lignans \\
\hline & 30.332 & 741.0 & Quercetin 3-O-xylosyl-rutinoside & Flavonols \\
\hline \multirow{10}{*}{ MF } & 3.667 & 377.1 & 3,4-DHPEA-EA & Tyrosols \\
\hline & 4.750 & 341.1 & Caffeic acid 4-O-glucoside & Hydroxycinnamic acids \\
\hline & 15.308 & 255.0 & Pterostilbene & Stilbenes \\
\hline & 19.304 & 337.1 & 3-p-Coumaroylquinic acid & Hydroxycinnamic acids \\
\hline & 22.135 & 275.1 & Unknown & \\
\hline & 26.898 & 593.1 & $\begin{array}{l}\text { Apigenin 6,8-di-C-glucoside } \\
\text { (Vicenin II) }\end{array}$ & Flavones \\
\hline & 27.844 & 593.1 & $\begin{array}{c}\text { Chrysoeriol 7-O-apiosyl-glucoside } \\
\text { Apigenin-6-C- }\end{array}$ & Methoxyflavones \\
\hline & 29.999 & 563.0 & $\begin{array}{l}\text { arabinoside-8-C-glucoside } \\
\text { (isoschaftoside) }\end{array}$ & Flavones \\
\hline & 31.224 & 328.2 & Avenanthramide $2 \mathrm{f}$ & Methoxycinnamic acids \\
\hline & 35.141 & 623.1 & $\begin{array}{l}\text { Isorhamnetin 3-O-glucoside } \\
\text { 7-O-rhamnoside }\end{array}$ & Methoxyflavonols \\
\hline
\end{tabular}

PF (pea flour), GBF (green bean flour), MF (mesquite flour).

MF was the sample with a variety of other compounds. Many compounds have been identified in different Prosopis species pods. In P. alba and P. pallida, the tentative phenolic compounds of isoschaftoside hexoside, schaftoside hexoside, vicenin II, isoschaftoside, schaftoside, vitexin, and isovitexin were identified [28]. The 1-methoxy-2-propyl acetate, methyldecylamine, hexadecanoic acid, ergosterol acetate, 2,4-dihydroxy-2,5-dimethyl$3(2 \mathrm{H})$-furan-3-one, and campesterol benzoate compounds were found in the ethanolic extract of $P$. juliflora pods [43]. Recently, Sharifi-Rad et al. [44] characterized the phenolic compounds in the species $P$. farcta through LC-ESI-QTOF-MS/MS. The P. farcta has many compounds, ranging from hydroxybenzoic, hydroxycinnamic, hydroxyphenyl acetic acids to flavanols, flavones, isoflavonoids, hydroxycoumarins, tyrosols, lignans, and stilbenes. In addition to vicenin II and isoschaftoside, other different compounds found in MF were pterostilbene and avenanthramide $2 \mathrm{f}$. It is important to highlight that avenanthramide $2 \mathrm{f}$, until now, has only been reported in oats [45].

In P. sativum species, the glycosylated flavonol has been described as the principal phenolic compound. Furthermore, other compounds well characterized in P. sativum are kaempferol, quercetin, p-coumaric, caffeic, ferulic, and cinnamic acids [46]. The hydroxycinnamic acid of p-coumaroyl tyrosine was found in the PF. 
According to Table 2, the highest polyphenol content and antioxidant activity were found in MF. The value of polyphenols content could be related to the antioxidant activity itself. The GBF phenolic compound and antioxidant activity values are similar to those reported by Aquino-Bolaños [31] in green bean landraces. The quantification of total phenolics in green beans reaches $4.9-10.1 \mathrm{mg} \mathrm{GA}$ eq/g dw and 23.4 to 45.6 and 14.2 to $44.8 \mu \mathrm{mol} \mathrm{TE} / \mathrm{g} \mathrm{dw}$ of antiradical activity when using the DPPH and FRAP methods, respectively. Regarding PF, Borges-Martínez et al. [47] studied the variations in the phenolic content and antioxidant activities during pea germination. In the ungerminated pea, the total phenolic content was $584.32 \mathrm{mg} \mathrm{GA} \mathrm{eq} / 100 \mathrm{~g}$. The antioxidant activities were $205.3 \mathrm{mg}$ $\mathrm{TE} / \mathrm{g}$ (DPPH) and $112.1 \mathrm{mg}$ TE/g (FRAP). Both the phenolic content and the antioxidant activities were higher than those obtained in PF.

Brizzolari et al. [48] reported a total phenolic content of $15.3 \mathrm{mg} \mathrm{GA} \mathrm{eq} / \mathrm{kg}$ for mesquite and antioxidant activity of $115 \mathrm{mmol} \mathrm{TE} / \mathrm{kg}$ (FRAP assay). In P. alba and P. nigra species, the total phenolic content was reported between $625-1150 \mathrm{mg} \mathrm{GA} \mathrm{eq} / \mathrm{kg}$, and antioxidant activity was reported between 5.4 and $10.02 \mu \mathrm{mol} \mathrm{TE} / 100 \mathrm{~g}$ sample (by $\mathrm{ABTS}^{ \pm}$) [34]. In $P$. chilensis and P. cineraria, the polyphenol content ranged from $0.82-2.57 \mathrm{~g}$ GA equivalent $/ 100 \mathrm{~g}$ and $0.21-13.59 \mathrm{mg}$ GA equivalent/100 g, respectively [49,50]. As these studies mention, most Prosopis species are known for their significant polyphenol compounds with high antioxidant activities.

\subsection{Functional Activities}

The effect of water absorption and retention at different process conditions is determined by the WAI (e.g., viscosity in food) [51]. Kraithong et al. [16] assessed the WAI in rice flour. The WAI of rice flour ranged between $5.44-7.14 \mathrm{~g} / \mathrm{g}$, similar to the WAI obtained in this study by GBF $(7.11 \mathrm{~g} / \mathrm{g})$. The high content of carbohydrates and proteins may contribute to stronger hydrogen bonding. The WSI in GBF was also higher $(80.61 \%)$, followed by PF with $73.66 \%$; these values indicate an increased number of water-soluble components; nevertheless, high WSI presents adverse effects such as a low ability to preserve food structure. In navy and pinto bean flowers, functional activities of WAI 0.95-1.43 g/g and WSI of $12.20 \%$, respectively [51], have been reported; these differences may be because GBF flour contains more polysaccharides (one of the hydrophilic constituents responsible of water absorption), including the whole pod. The WAI and WSI reported in the mesquite pod flours $2.53 \mathrm{~g} / \mathrm{g}$ and $36.36 \%$ [52], respectively, similar to the WAI obtained in this study $(2.28 \mathrm{~g} / \mathrm{g})$, but the WSI was higher $(64.87 \%)$.

Water holding capacity is related to a material's ability, mainly that of proteins, to hold water against gravity; it plays a vital role in releasing the nutritional components of food [53]. Meanwhile, oil holding is associated with the fiber structure [17]. GBF was the sample with the higher WHC (5.77 g water/g sample) (Table 2); despite PF having higher protein content, the nature of the GBF proteins confers this advantage. On the other hand, in raw pinto bean flour, the values of $\mathrm{WHC}$ and $\mathrm{OHC}$ were $1.7 \mathrm{~g}$ water $/ \mathrm{g}$ sample and $1.4 \mathrm{~g}$ oil $/ \mathrm{g}$ sample [54]. In pea pod fibers, an OHC of $2.85 \mathrm{~g}$ oil $/ \mathrm{g}$ sample and a WHC of $4.64 \mathrm{~g}$ water/g sample [55] have been reported. These results are specific for fiber; the interaction between other components and particle sizes affect the matrix and affect these properties [17].

In the case of the OMAC, it is related to the insoluble dietary fiber content; hence, higher OMAC values implied that the samples would have efficient interactions with fat, bile acids, cholesterol, and toxic compounds [56]. The OMAC values ranged between $1.60-2.03 \mathrm{~g}$ oil $/ \mathrm{g}$ sample in the evaluated flours, and no significant differences were found among them.

\subsection{Bread Characterization}

Table 4 shows the obtained results of the different bread treatments. The fat results are not presented because they were not detected in any sample; this may be because of the low-fat nature of the legume flours and the whole wheat flour. In all of the treatments, the 
moisture content corresponds to the value of this kind of food between 38-43\% [57]. No significant difference was found in ash content, but it is essential to notice that each legume added different minerals types. The bread with MF showed the best fiber parameter, and this was expected, as MF has a higher content than the other flours. Bigne et al. [58] described that the addition of $P$. alba increases the mineral and fiber content of bread.

Another significant difference between the treatments was the carbohydrate content. In this case, the control was higher in carbohydrates, and treatment 1 (with PF and GBF) had the lower content. Between the flours, WF is higher in carbohydrates (54\%), and the lower content is in PF. Compared to the other bread with legume flour added, the carbohydrate content is lower. For bread with $30 \mathrm{~g}$ of pea flour, Millar et al. [59] reported $50.6 \%$ carbohydrate content; in bread with portions of 5 to $15 \%$ of P. pallida flour, GonzalesBarron et al. [39] reported a carbohydrate content between 54 to $55 \%$.

Regarding the protein content, the treatment with the addition of GBF and PF had higher content. It is known that the incorporation of legumes has an impact on nutritional properties and technological properties. The effect on technological properties is negative, as the low molecular weight proteins interfere in the gluten structure [26]. Hence, the obtained bread may have a lower volume or higher hardness. Samples with the three flours and the combination of PF and GBF presented lower specific volume values than the control (Figure 1); this can also be attributed to the WSI value since high values affect bread structure preservation. Millar et al. [59] described the addition of yellow pea flour into white bread; compared to the control, substituting $30 \%$ of the wheat flour with pea flour decreased the specific bread volume by $19.52 \%$. However, in the present study, the $20 \%$ PF (treatment 5) substitution in the dough decreased the bread-specific volume by approximately $11 \%$. In the case of the GBF addition, the specific volume decreased around $27 \%$ (treatment 6); this is comparable with the specific volume values obtained by the 15 and $25 \%$ substitution of red kidney bean in bread, where the volume decreased 30.32 and $33.47 \%$, respectively [36]. The substitution with MF only reduced the volume by about $7 \%$. The 15, 25, and $35 \mathrm{~g} / 100 \mathrm{~g}$ replacement of P. alba in bread led to a volume reduction of 5, 7, and $28 \%$ [58].

The luminosity of any treatment was not affected in terms of the color parameters, but there are differences in $a^{*}$ and $b^{*}$. As $a^{*}$ represents the color green to red and as $b^{*}$ represents blue to yellow, the GBF or PF treatments have differences in these parameters because of the greenish color.

Concerning the bread calories, there are no significant differences between treatments, and values are in a range of 217 to $226 \mathrm{kcal} / 100 \mathrm{~g}$. These results are comparable with the calories in bread with P. pallida (355 kcal/100 g) [39] and wholemeal, multi cereal, rye, and oat bread that have values of 242 to $265 \mathrm{kcal} / 100 \mathrm{~g}$ [60].

No major differences were found amid treatments for the polyphenol and antioxidant activities. It has been reported that whole wheat grain cereals are a good source of antioxidants. Moreover, one of the advantages of sourdough is the potentiation of nutritional and functional capacities.

Despite the significant differences in the flour's functional properties, the higher WHC and OHC values correspond to the control bread. These results may be due to protein denaturation during baking or protein degradation during sourdough fermentation [61]. Contrastingly, as the OHC depends on the surface properties, this surface may change in the final product [17]. Moreover, as aguamiel is a carbohydrate source, the sugar molecules bind to water, decrease water activity, and delay the development of the gluten network [62]. The Pearson test presented important correlations between fiber and WHC $(\mathrm{r}=-0.72, p=0.0001)$, fiber and OHC $(\mathrm{r}=-0.50, p=0.0085)$, and WHC and OHC $(\mathrm{r}=-0.54, p=0.0035)$. 
Table 4. Proximal composition, antioxidant, and functional activities of sourdough loaves of bread.

\begin{tabular}{|c|c|c|c|c|c|c|c|c|}
\hline \multicolumn{9}{|c|}{ Bread Treatments } \\
\hline Proximal Composition (g/100 g) & 1 & 2 & 3 & 4 & 5 & 6 & 7 & Control \\
\hline Moisture & $36.60 \pm 1.61^{a *}$ & $35.98 \pm 2.05^{a}$ & $34.31 \pm 1.05^{\mathrm{a}}$ & $35.74 \pm 2.05^{a}$ & $34.93 \pm 1.42^{\mathrm{a}}$ & $36.13 \pm 2.46^{a}$ & $33.25 \pm 2.91^{a}$ & $38.56 \pm 1.60^{\mathrm{a}}$ \\
\hline Ash & $3.29 \pm 0.21^{\mathrm{a}}$ & $3.95 \pm 0.75^{\mathrm{a}}$ & $3.33 \pm 0.43^{\mathrm{a}}$ & $3.24 \pm 0.11^{\mathrm{a}}$ & $3.43 \pm 0.24^{\mathrm{a}}$ & $3.62 \pm 0.25^{\mathrm{a}}$ & $3.81 \pm 0.94^{\mathrm{a}}$ & $2.85 \pm 0.58^{\mathrm{a}}$ \\
\hline Total fiber & $5.18 \pm 0.16^{b c}$ & $4.42 \pm 0.48^{b c}$ & $5.40 \pm 0.29 \mathrm{abc}$ & $5.63 \pm 0.20^{\mathrm{ab}}$ & $5.18 \pm 0.29 \mathrm{bc}$ & $4.24 \pm 0.47^{\mathrm{c}}$ & $6.45 \pm 0.90^{\mathrm{a}}$ & $2.63 \pm 0.24^{d}$ \\
\hline Protein & $19.77 \pm 2.70^{\mathrm{a}}$ & $15.35 \pm 0.49^{a b}$ & $16.05 \pm 2.99 \mathrm{ab}$ & $17.40 \pm 0.42^{\mathrm{ab}}$ & $18.02 \pm 0.03^{\mathrm{ab}}$ & $18.45 \pm 0.64^{\mathrm{ab}}$ & $14.56 \pm 1.53^{\mathrm{ab}}$ & $13.13 \pm 1.22^{b}$ \\
\hline Carbohydrates & $34.54 \pm 0.61^{\mathrm{b}}$ & $40.56 \pm 3.93^{\mathrm{ab}}$ & $41.88 \pm 2.73^{\mathrm{ab}}$ & $37.99 \pm 2.18^{\mathrm{ab}}$ & $37.39 \pm 0.06^{\mathrm{ab}}$ & $35.94 \pm 2.18^{a b}$ & $40.27 \pm 0.60 \mathrm{ab}$ & $43.40 \pm 0.82^{\mathrm{a}}$ \\
\hline Caloric value (kcal/100 g) & $217.24 \pm 8.37^{a}$ & $223.65 \pm 17.71^{\mathrm{a}}$ & $231.69 \pm 1.03^{a}$ & $221.54 \pm 10.38^{a}$ & $221.64 \pm 0.35^{\mathrm{a}}$ & $217.56 \pm 6.18^{a}$ & $219.29 \pm 3.72^{a}$ & $226.09 \pm 8.17^{\mathrm{a}}$ \\
\hline \multicolumn{9}{|l|}{ Color parameters } \\
\hline$L^{*}$ & $47.28 \pm 3.64^{a}$ & $42.03 \pm 4.20^{\mathrm{a}}$ & $40.65 \pm 6.13^{a}$ & $40.88 \pm 6.14^{\mathrm{a}}$ & $44.97 \pm 3.18^{a}$ & $46.37 \pm 0.75^{\mathrm{a}}$ & $39.24 \pm 3.18^{a}$ & $38.03 \pm 3.49^{a}$ \\
\hline$a^{*}$ & $8.27 \pm 0.55^{\mathrm{c}}$ & $8.94 \pm 0.29 \mathrm{abc}$ & $8.86 \pm 0.27^{\mathrm{abc}}$ & $8.82 \pm 0.39 \mathrm{abc}$ & $8.52 \pm 0.71 \mathrm{bc}$ & $7.72 \pm 0.46^{\mathrm{c}}$ & $9.88 \pm 0.70^{a b}$ & $10.10 \pm 0.50^{\mathrm{a}}$ \\
\hline$b^{*}$ & $21.08 \pm 0.61^{\mathrm{a}}$ & $19.25 \pm 0.55^{\mathrm{ab}}$ & $18.51 \pm 0.88^{a b c}$ & $19.44 \pm 1.03^{\mathrm{ab}}$ & $20.06 \pm 1.08^{a}$ & $20.91 \pm 1.39^{a}$ & $16.89 \pm 1.06^{b c}$ & $16.48 \pm 0.77^{c}$ \\
\hline Total Polyphenols (mg GA eq/g) & $392.16 \pm 91.64^{\mathrm{a}}$ & $433.32 \pm 98.87^{a}$ & $430.71 \pm 57.16^{\mathrm{a}}$ & $436.07 \pm 34.57^{\mathrm{a}}$ & $401.87 \pm 52.64^{\mathrm{a}}$ & $396.94 \pm 85.04^{a}$ & $630.57 \pm 266.60^{a}$ & $350.28 \pm 59.51^{\mathrm{a}}$ \\
\hline \multicolumn{9}{|l|}{$\begin{array}{l}\text { Antioxidant activity (mg Trolox } \\
\text { eq/g) }\end{array}$} \\
\hline ABTS & $91.15 \pm 3.87^{\mathrm{a}}$ & $85.46 \pm 14.72^{a}$ & $95.13 \pm 0.86^{\mathrm{a}}$ & $94.64 \pm 0.37^{\mathrm{a}}$ & $93.50 \pm 2.91^{\mathrm{a}}$ & $91.07 \pm 6.59^{\mathrm{a}}$ & $92.24 \pm 3.11^{\mathrm{a}}$ & $91.96 \pm 3.07^{\mathrm{a}}$ \\
\hline FRAP & $920.68 \pm 190.08^{a}$ & $923.67 \pm 153.24^{\mathrm{a}}$ & $992.79 \pm 91.13^{\mathrm{a}}$ & $995.95 \pm 99.85^{a}$ & $961.04 \pm 198.43^{a}$ & $908.93 \pm 274.54^{\mathrm{a}}$ & $995.07 \pm 132.92^{\mathrm{a}}$ & $809.24 \pm 203.44^{c}$ \\
\hline \multicolumn{9}{|l|}{ Functional properties } \\
\hline WHC (g water/g sample) & $1.03 \pm 0.06^{\mathrm{d}}$ & $1.63 \pm 0.15^{\mathrm{ab}}$ & $1.40 \pm 0.20^{b c}$ & $1.37 \pm 0.12^{a b c}$ & $1.10 \pm 0.10^{b c}$ & $1.27 \pm 0.12^{b c}$ & $1.07 \pm 0.12^{b c}$ & $1.87 \pm 0.12^{\mathrm{a}}$ \\
\hline OHC (g oil/ g sample) & $0.43 \pm 0.02 \mathrm{bc}$ & $0.50 \pm 0.05^{\mathrm{a}}$ & $0.32 \pm 0.04^{\mathrm{c}}$ & $0.40 \pm 0.01 \mathrm{abc}$ & $0.36 \pm 0.04 \mathrm{bc}$ & $0.33 \pm 0.01 \mathrm{bc}$ & $0.35 \pm 0.05^{b c}$ & $0.49 \pm 0.05^{\mathrm{a}}$ \\
\hline
\end{tabular}

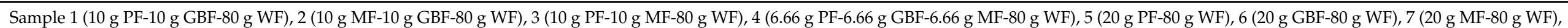

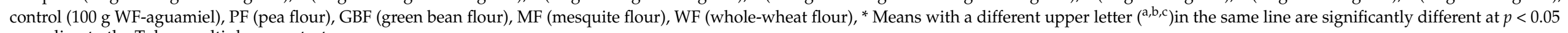
according to the Tukey multiple range test. 


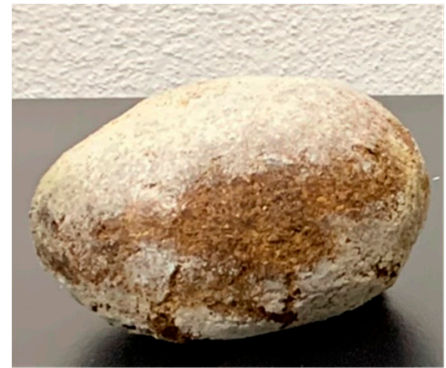

1

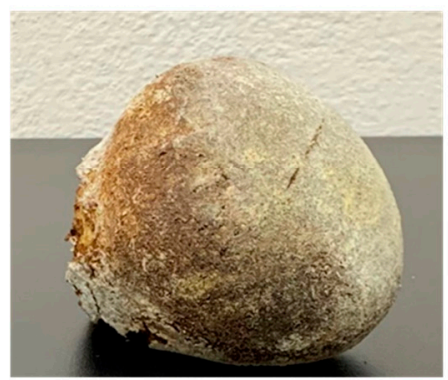

5

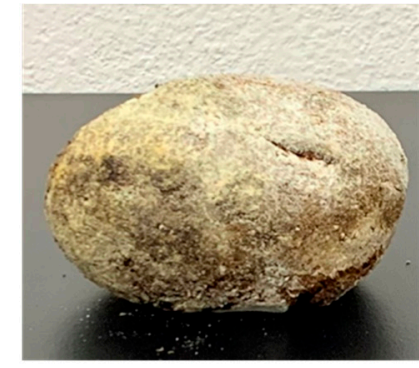

2

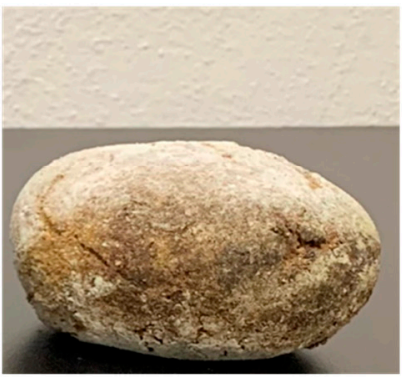

6

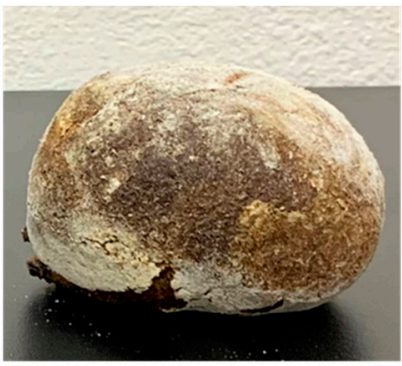

3

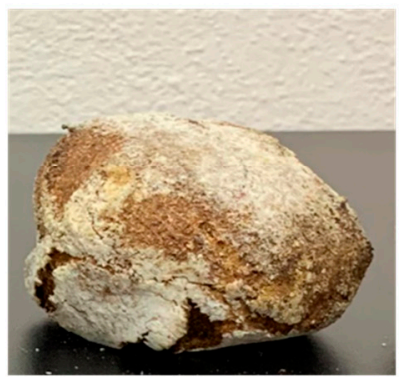

7

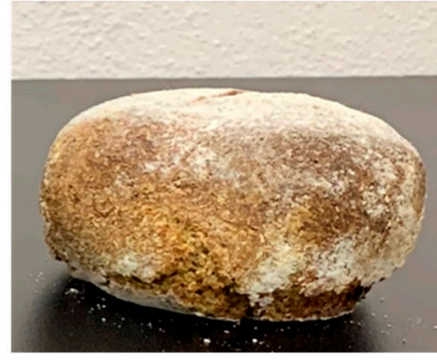

4

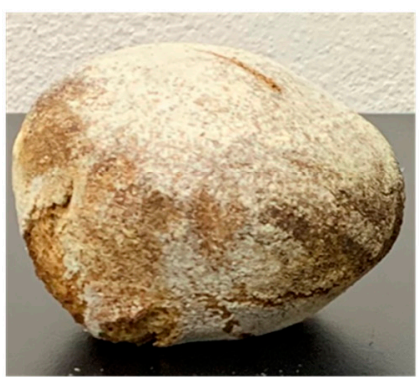

Control

Figure 1. Visual appearance of bread treatments. Picture 1 (10 g PF-10 g GBF-80 g WF), 2 (10 g MF-10 g GBF-80 g WF), 3 (10 g PF-10 g MF-80 g WF), 4 (6.66 g PF-6.66 g GBF-6.66 g MF-80 g WF), 5 (20 g PF-80 g WF), 6 (20 g GBF-80 g WF), 7 (20 g MF-80 $\mathrm{g}$ WF), control (100 g WF-aguamiel), PF (pea flour), GBF (green bean flour), MF (mesquite flour), WF (whole-wheat flour).

\subsection{Mathematical Model}

The presented contour graphics in Figure 2 visually display the effect of the different flours on fiber, protein, carbohydrates, color parameters $\mathrm{a}^{*}$ and $\mathrm{b}^{*}$, and specific volume. In the graphics, the color scale presented on the right (ranging from blue to red) goes from lower to higher values. Visually, e.g., for fiber values, a high amount of MF flour is need to increase this parameter, and a higher amount of GBF is needed to decrease fiber. To describe and define these effects, a special cubic model was the best fit for the evaluated variables. The equations of the parameters that had a major influence on the samples were fiber $=2.75 \times \mathrm{WF}+5.35829 \times \mathrm{PF}+4.21429 \times \mathrm{GBF}+6.07029 \times \mathrm{MF}\left(\mathrm{R}^{2}=90.98\right)$, protein $=13.13 \times \mathrm{WF}+18.5764 \times \mathrm{PF}+18.6404 \times \mathrm{GBF}+14.0404 \times \mathrm{MF}\left(\mathrm{R}^{2}=90.90\right)$, carbohydrates $=38.03 \times \mathrm{WF}+36.9605 \times \mathrm{PF}+35.2725 \times \mathrm{GBF}+44.2485 \times \mathrm{MF}$ $\left(\mathrm{R}^{2}=89.61\right), \mathrm{a}^{*}=9.9 \times \mathrm{WF}+8.46638 \times \mathrm{PF}+7.85838 \times \mathrm{GBF}+9.82238 \times \mathrm{MF}$ $\left(\mathrm{R}^{2}=95.56\right), \mathrm{b}^{*}=16.23 \times \mathrm{WF}+20.2126 \times \mathrm{PF}+21.1886 \times \mathrm{GBF}+16.9446 \times \mathrm{MF}$ $\left(\mathrm{R}^{2}=98.57\right)$, and specific volume $=1.73 \times \mathrm{WF}+1.38724 \times \mathrm{PF}+1.18324 \times \mathrm{GBF}+1.47524 \times$ MF $\left(R^{2}=86.51\right)$.

According to the equations, the three legume flours significantly influenced the fiber content, due to its higher value coefficient, the highest impact is due to MF. For the protein value, the significant influence is caused by GBF and PF; meanwhile, MF has a considerable effect on the carbohydrate content.

In $\mathrm{a}^{*}$, there is a synergistic effect because of the similarity in the coefficients, but in $\mathrm{b}^{*}$, the principal effects are those from the PF and GBF. As the legume flours tend to decrease volume, this parameter's positive impact comes from the WF. 

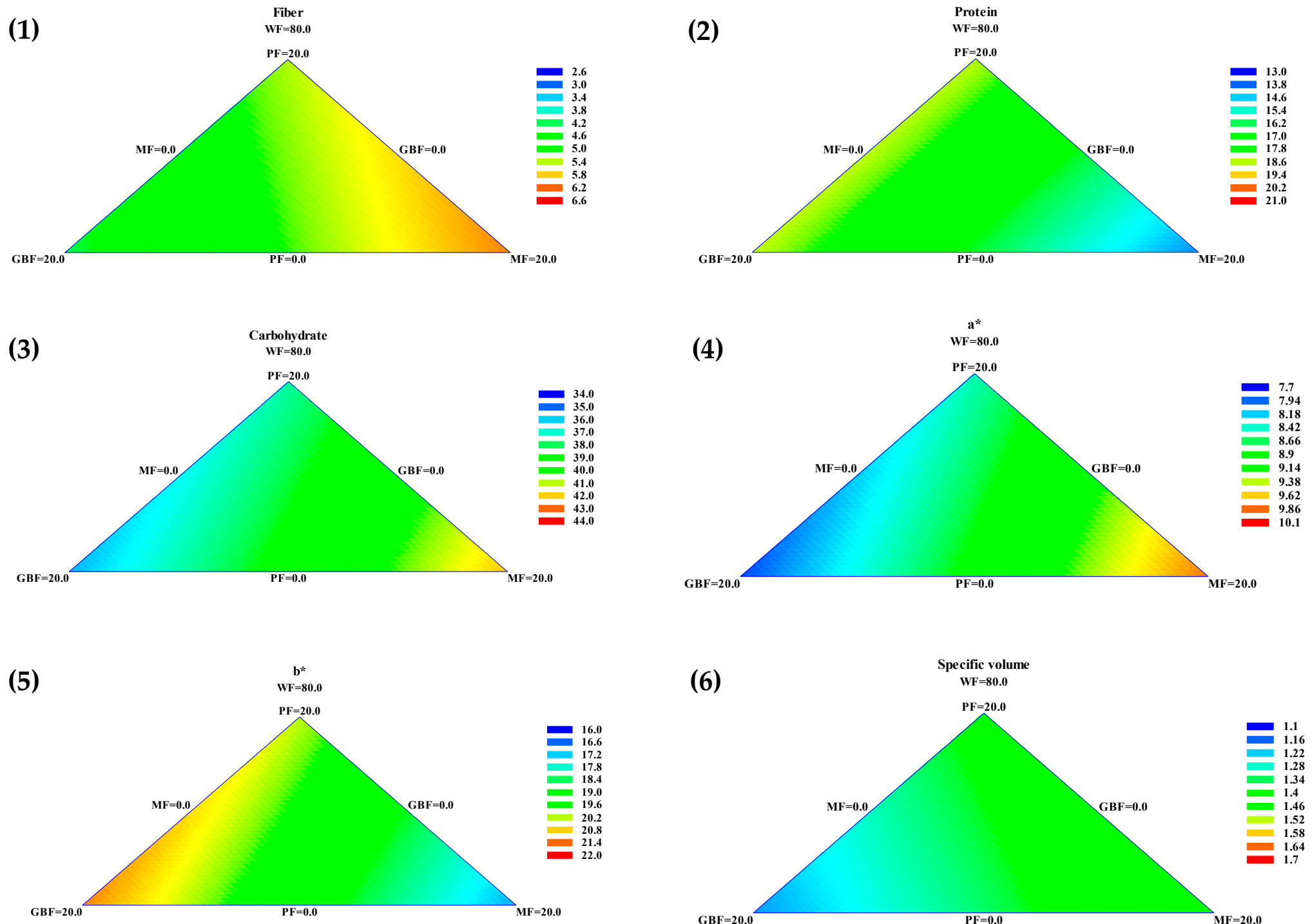

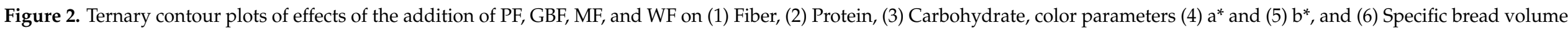




\section{Conclusions}

The evaluated legumes presented differences in their proximal composition, mineral content, and antioxidant activities, compared to similarly reported legumes. As the legumes become more important for their nutritional value, their characterization allows whole pods or less-known species to be used.

The pea flour analyzed in this study presented higher protein content compared to other reported pea flours. Green bean flour also showed benefits compared to the red, white, and black beans, making it another option with high protein and a higher mineral content. Additionally, the mesquite flour significantly contributed to the fiber content and significant antioxidant activities. It was possible to obtain bread with a relevant fiber content and with similar color and specific volume than the control. With the obtained mathematical model and more studies of the bread matrix, it is possible to optimize bread potential.

Author Contributions: Conceptualization, J.F.S.-D., A.C.F.-G. and R.R.-H.; data curation, A.M.G.-M.; formal analysis, A.M.G.-M.; funding acquisition, A.C.F.-G. and R.R.-H.; investigation, C.M.L.-B. and J.A.A.-V.; methodology, A.M.G.-M., J.F.S.-D. and A.C.F.-G.; supervision, A.C.F.-G. and R.R.-H.; writing—original draft, A.M.G.-M.; writing—review and editing, A.M.G.-M., J.F.S.-D., A.C.F.-G., C.M.L.-B., J.A.A.-V. and R.R.-H. All authors have read and agreed to the published version of the manuscript.

Funding: This research received no external funding.

Institutional Review Board Statement: Not applicable.

Informed Consent Statement: Not applicable.

Data Availability Statement: The data presented in this study are available on request from the corresponding author. The data are not publicly available due to privacy.

Acknowledgments: This study had financial support from the Universidad Autónoma de Coahuila. González-Montemayor is grateful for receiving funding from the National Council of Science and Technology-Mexico (CONACyT) during her doctoral studies.

Conflicts of Interest: The authors declare no conflict of interest.

\section{References}

1. Martins, Z.E.; Pinho, O.; Ferreira, I.M.P.L.V.O. Food industry by-products used as functional ingredients of bakery products. Trends Food Sci. Technol. 2017, 67, 106-128. [CrossRef]

2. Hager, A.S.; Zannini, E.; Arendt, E.K. Formulating breads for specific dietary requirements. In Breadmaking: Improving Quality; Cauvain, S.P., Ed.; Elsevier: Amsterdam, The Netherlands, 2012; pp. 711-735.

3. Collar, C. Bread: Types of Bread. In Encyclopedia of Food and Health; Caballero, B., Finglas, P.M., Toldrá, F., Eds.; Elsevier Ltd.: Amsterdam, The Netherlands, 2016; pp. 500-507.

4. Sáez, G.D.; Saavedra, L.; Hebert, E.M.; Zárate, G. Identification and biotechnological characterization of lactic acid bacteria isolated from chickpea sourdough in northwestern Argentina. LWT 2018, 93, 249-256. [CrossRef]

5. Tuncel, N.B.; Yilmaz, N.; Sener, E. The effect of pea (Pisum sativum L.)-originated asparaginase on acrylamide formation in certain bread types. Int. J. Food Sci. Technol. 2010, 45, 2470-2476. [CrossRef]

6. Bourré, L.; McMillin, K.; Borsuk, Y.; Boyd, L.; Lagassé, S.; Sopiwnyk, E.; Jones, S.; Dick, A.; Malcolmson, L. Effect of adding fermented split yellow pea flour as a partial replacement of wheat flour in bread. Legum. Sci. 2019, 1, e2. [CrossRef]

7. Ukeyima, M.T.; Dendegh, T.A.; Isusu, S.E. Quality Characteristics of Bread Produced from Wheat and White Kidney Bean Composite Flour. Eur. J. Nutr. Food Saf. 2019, 10, 263-272. [CrossRef]

8. Hoxha, I.; Xhabiri, G.; Deliu, R. The Impact of Flour from White Bean (Phaseolus vulgaris) on Rheological, Qualitative and Nutritional Properties of the Bread. Open Access Libr. J. 2020, 7, 1-8. [CrossRef]

9. González-Montemayor, A.M.; Flores-Gallegos, A.C.; Contreras-Esquivel, J.C.; Solanilla-Duque, J.F.; Rodríguez-Herrera, R. Prosopis spp. functional activities and its applications in bakery products. Trends Food Sci. Technol. 2019, 94, 12-19. [CrossRef]

10. Galli, V.; Venturi, M.; Pini, N.; Guerrini, S.; Granchi, L.; Vincenzini, M. Liquid and firm sourdough fermentation: Microbial robustness and interactions during consecutive backsloppings. LWT 2019, 105, 9-15. [CrossRef]

11. Official Methods of Analysis AOAC Intternational; AOAC: Rockville, MD, USA, 2000.

12. Chen, D.; Shi, J.; Hu, X.; Du, S. Alpha-amylase treatment increases extractable phenolics and antioxidant capacity of oat (Avena nuda L.) flour. J. Cereal Sci. 2015, 65, 60-66. [CrossRef] 
13. Hernández-Hernández, C.; Aguilar, C.N.; Flores-Gallegos, A.C.; Sepúlveda, L.; Rodríguez-Herrera, R.; Morlett-Chávez, J.; Govea-Salas, M.; Ascacio-Valdés, J. Preliminary testing of ultrasound/microwave-assisted extraction (U/M-AE) for the isolation of Geraniin from Nephelium lappaceum L. (Mexican Variety) peel. Processes 2020, 8, 572. [CrossRef]

14. Molyneux, P. The Use of the Stable Free Radical Diphenylpicryl-hydrazyl (DPPH) for Estimating Antioxidant Activity. Songklanakarin J. Sci. Technol. 2004, 26, 211-219. [CrossRef]

15. Opitz, S.E.W.; Smrke, S.; Goodman, B.A.; Yeretzian, C. Methodology for the measurement of antioxidant capacity of coffee: A validated platform composed of three complementary antioxidant assays. In Processing and Impact on Antioxidants in Beverages; Preedy, V., Ed.; Elsevier: Amsterdam, The Netherlands, 2014; pp. 253-264.

16. Kraithong, S.; Lee, S.; Rawdkuen, S. Physicochemical and functional properties of Thai organic rice flour. J. Cereal Sci. 2018, 79, 259-266. [CrossRef]

17. Escobedo-García, S.; Salas-Tovar, J.A.; Flores-Gallegos, A.C.; Contreras-Esquivel, J.C.; González-Montemayor, A.M. Functionality of Agave Bagasse as Supplement for the Development of Prebiotics-Enriched Foods. Plant. Foods Hum. Nutr. 2019, 75, 96-102. [CrossRef] [PubMed]

18. Lira, A.Q.; Alvarado-Resendiz, M.G.; Simental, S.S.; Martini, J.P.; Reyes-Santamaria, M.I.; Guemes-Vera, N. Use of Lactobacillus from Pulque in Sourdough. Adv. Microbiol. 2014, 4, 969-977. [CrossRef]

19. Villarreal Morales, S.L.; Muñiz Márquez, D.B.; Michel Michel, M.; González Montemayor, A.M.; Escobedo García, S.; Salas Tovar, J.A.; Flores Gallegos, A.C.; Rodríguez Herrera, R. Aguamiel a fresh beverage from Agave spp. sap with functional properties. In Natural Beverages; Grumezescu, A.M., Holban, A.M., Eds.; Woodhead Publishing: Sawston, UK, 2019; pp. 179-208.

20. AACC International Approved methods of analysis. In Approved Methods of Analysis, 11th ed.; AACC International: Saint Paul, MN, USA, 2010.

21. Purić, M.; Rabrenović, B.; Rac, V.; Pezo, L.; Tomašević, I.; Demin, M. Application of defatted apple seed cakes as a by-product for the enrichment of wheat bread. LWT 2020, 130, 109391. [CrossRef]

22. Saldanha do Carmo, C.; Silventoinen, P.; Nordgård, C.T.; Poudroux, C.; Dessev, T.; Zobel, H.; Holtekjølen, A.K.; Draget, K.I.; Holopainen-Mantila, U.; Knutsen, S.H.; et al. Is dehulling of peas and faba beans necessary prior to dry fractionation for the production of protein-and starch-rich fractions? Impact on physical properties, chemical composition and techno-functional properties. J. Food Eng. 2020, 278, 109937. [CrossRef]

23. Kan, L.; Nie, S.; Hu, J.; Wang, S.; Cui, S.W.; Li, Y.; Xu, S.; Wu, Y.; Wang, J.; Bai, Z.; et al. Nutrients, phytochemicals and antioxidant activities of 26 kidney bean cultivars. Food Chem. Toxicol. 2017, 108, 467-477. [CrossRef] [PubMed]

24. Conforti, P.A.; Patrignani, M. Increase in the antioxidant content in biscuits by infusions or Prosopis chilensis pod flour. Open Agric. 2021, 6, 243-253. [CrossRef]

25. Michaels, T.E. Grain Legumes and Their Dietary Impact: Overview. In Encyclopedia of Food Grains; Wrigley, C., Corke, H., Seetharaman, K., Faubion, J., Eds.; Academic Press Limited: Cambridge, MA, USA, 2016; Volume 1-4, pp. $265-273$.

26. Millar, K.A.; Gallagher, E.; Burke, R.; Mccarthy, S.; Barry-ryan, C. Proximate composition and anti-nutritional factors of fava-bean (Vicia faba), green-pea and yellow-pea (Pisum sativum) flour. J. Food Compos. Anal. 2019, 82, 103233. [CrossRef]

27. Sciammaro, L.P.; Ferrero, C.; Puppo, C. Physicochemical and nutritional characterization of sweet snacks formulated with Prosopis alba flour. LWT 2018, 93, 24-31. [CrossRef]

28. Gonzales-Barron, U.; Dijkshoorn, R.; Maloncy, M.; Finimundy, T.; Calhelha, R.C.; Pereira, C.; Stojković, D.; Soković, M.; Ferreira, I.C.F.R.; Barros, L.; et al. Nutritive and bioactive properties of mesquite (Prosopis pallida) flour and its technological performance in breadmaking. Foods 2020, 9, 597. [CrossRef] [PubMed]

29. Romano, N.; Sciammaro, L.; Mobili, P.; Puppo, M.C.; Gomez-Zavaglia, A. Flour from mature Prosopis nigra pods as suitable substrate for the synthesis of prebiotic fructo-oligosaccharides and stabilization of dehydrated Lactobacillus delbrueckii subsp. bulgaricus. Food Res. Int. 2019, 121, 561-567. [CrossRef] [PubMed]

30. Arteaga, V.G.; Kraus, S.; Schott, M.; Muranyi, I.; Schweiggert-Weisz, U.; Eisner, P. Screening of twelve pea (Pisum sativum L.) cultivars and their isolates focusing on the protein characterization, functionality, and sensory profiles. Foods 2021, 10, 758. [CrossRef] [PubMed]

31. Aquino-Bolaños, E.N.; Garzón-García, A.K.; Alba-Jiménez, J.E.; Chávez-Servia, J.L.; Vera-Guzmán, A.M.; Carrillo-Rodríguez, J.C.; Santos-Basurto, M.A. Physicochemical Characterization and Functional Potential of Phaseolus vulgaris L. and Phaseolus coccineus L. Landrace green beans. Agronomy 2021, 11, 803. [CrossRef]

32. Mateos-Aparicio, I.; Redondo-Cuenca, A.; Villanueva-Suárez, M.J.; Zapata-Revilla, M.A.; Tenorio-Sanz, M.D. Pea pod, broad bean pod and okara, potential sources of functional compounds. LWT 2010, 43, 1467-1470. [CrossRef]

33. Falade, K.O.; Akeem, S.A. Protein quality of dehulled-defatted African mesquite bean (Prosopis africana) flour and protein isolates. J. Food Meas. Charact. 2020, 14, 3426-3433. [CrossRef]

34. Sciammaro, L.P.; Quintero Ruiz, N.A.; Ferrero, C.; Giacomino, S.; Picariello, G.; Mamone, G.; Puppo, M.C. Prosopis spp. powder: Influence of chemical components in water adsorption properties. Int. J. Food Sci. Technol. 2021, 56, 278-286. [CrossRef]

35. Veber, A.; Zareba, D.; Ziarno, M. Functional fermented beverage prepares from germinated white kidney beans (Phaseolus vulgaris L.). In Milk Substitutes-Selected Aspects; Ziarno, M., Ed.; IntechOpen: London, UK, 2021; pp. 3-22.

36. Manonmani, D.; Bhol, S.; Bosco, S.J.D. Effect of Red Kidney Bean (Phaseolus vulgaris L.) Flour on Bread Quality. Open Access Libr. J. 2014, 3, 1-6. [CrossRef] 
37. Pitura, K.; Arnt, S.D. Characteristics of flavonol glycosides in bean (Phaseolus vulgaris L.) seed coats. Food Chem. 2019, 272 , 26-32. [CrossRef]

38. Gebreegziabher, B.G.; Tsegay, B.A. Proximate and mineral composition of Ethiopian pea (Pisum sativum var. abyssinicum A. Braun) landraces vary across altitudinal ecosystems. Cogent Food Agric. 2020, 6, 1789421. [CrossRef]

39. Gonzales-Barron, U.; Dijkshoorn, R.; Maloncy, M.; Finimundy, T.; Carocho, M.; Ferreira, I.C.F.R.; Barros, L.; Cadavez, V. Nutritional quality and staling of wheat bread partially replaced with Peruvian mesquite (Prosopis pallida) flour. Food Res. Int. 2020, 137, 109621. [CrossRef]

40. Anhwange, B.; Kyenge, B.; Kukwa, R.; Ishwa, B. Chemical Analysis of Prosopis africana (Guill \&Perr.) Seeds. Niger. Ann. Pure Appl. Sci. 2020, 3, 129-140. [CrossRef]

41. Santiago-Ramos, D.; de Dios Figueroa-Cárdenas, J.; Véles-Medina, J.J.; Salazar, R. Physicochemical properties of nixtamalized black bean (Phaseolus vulgaris L.) flours. Food Chem. 2018, 240, 456-462. [CrossRef]

42. Rodríguez Madrera, R.; Campa Negrillo, A.; Suárez Valles, B.; Ferreira Fernández, J.J. Phenolic content and antioxidant activity in seeds of common bean (Phaseolus vulgaris L.). Foods 2021, 10, 864. [CrossRef] [PubMed]

43. Malik, S.K.; Ahmed, M.; Khan, F. Identification of novel anticancer terpenoids from Prosopis juliflora (Sw) DC (Leguminosae) pods. Trop. J. Pharm. Res. 2018, 17, 661-668. [CrossRef]

44. Sharifi-Rad, J.; Zhong, J.; Ayatollahi, S.A.; Kobarfard, F.; Faizi, M.; Khosravi-Dehaghi, N.; Suleria, H.A.R. LC-ESI-QTOF-MS/MS characterization of phenolic compounds from Prosopis farcta (Banks \& Sol.) J.F.Macbr. And their potential antioxidant activities. Cell. Mol. Biol. 2021, 67, 189-200. [CrossRef]

45. Schendel, R.R. Phenol content in sprouted grains. In Sprouted Grains; Feng, H., Nemzer, B., DeVries, J.W., Eds.; Elsevier Inc.: Amsterdam, The Netherlands, 2019; pp. 247-316.

46. Fahim, J.R.; Attia, E.Z.; Kamel, M.S. The phenolic profile of pea (Pisum sativum): A phytochemical and pharmacological overview. Phytochem. Rev. 2019, 18, 173-198. [CrossRef]

47. Borges-Martínez, E.; Gallardo-Velázquez, T.; Cardador-Martínez, A.; Moguel-Concha, D.; Osorio-Revilla, G.; Ruiz-Ruiz, J.C.; Martínez, C.J. Phenolic compounds profile and antioxidant activity of pea (Pisum sativum L.) and black bean (Phaseolus vulgaris L.) sprouts. Food Sci. Technol. 2021, 2061, 1-7. [CrossRef]

48. Brizzolari, A.; Brandolini, A.; Glorio-Paulet, P.; Hidalgo, A. Antioxidant capacity and heat damage of powder products from South American plants with functional properties. Ital. J. Food Sci. 2019, 31, 731-748. [CrossRef]

49. Schmeda-Hirschmann, G.; Quispe, C.; Soriano, M.D.P.C.; Theodoluz, C.; Jiménez-Aspée, F.; Pérez, M.J.; Cuello, A.S.; Isla, M.I. Chilean Prosopis Mesocarp Flour: Phenolic Profiling and Antioxidant Activity. Molecules 2015, 20, 7017-7033. [CrossRef] [PubMed]

50. Kumar, M.; Govindasamy, J.; Nyola, N.K. In-vitro and in-vivo Anti-Hyperglycemic Potential of Prosopis cineraria Pods Extract and Fractions. J. Biol. Act. Prod. Nat. 2019, 9, 135-140. [CrossRef]

51. Siddiq, M.; Kelkar, S.; Harte, J.B.; Dolan, K.D.; Nyombaire, G. Functional properties of flour from low-temperature extruded navy and pinto beans (Phaseolus vulgaris L.). LWT 2013, 50, 215-219. [CrossRef]

52. De La Rosa, A.P.; Frias-Hernández, J.T.; Olalde-Portugal, V.; González Castañeda, J. Processing, Nutritional Evaluation, and Utilization of Whole Mesquite Flour (Prosopis laevigata). J. Food Sci. 2006, 71, 315-320. [CrossRef]

53. Wu, C.; Ma, W.; Chen, Y.; Navicha, W.B.; Wu, D.; Du, M. The water holding capacity and storage modulus of chemical cross-linked soy protein gels directly related to aggregates size. LWT 2019, 103, 125-130. [CrossRef]

54. Lin, T.; Fernández-Fraguas, C. Effect of thermal and high-pressure processing on the thermo-rheological and functional properties of common bean (Phaseolus vulgaris L.) flours. LWT 2020, 127, 109325. [CrossRef]

55. Belghith Fendri, L.; Chaari, F.; Maaloul, M.; Kallel, F.; Abdelkafi, L.; Ellouz Chaabouni, S.; Ghribi-Aydi, D. Wheat bread enrichment by pea and broad bean pods fibers: Effect on dough rheology and bread quality. LWT 2016, 73, 584-591. [CrossRef]

56. Nyam, K.L.; Lau, M.; Tan, C.P. Fibre from pumpkin (Cucurbita pepo L.) Seeds and rinds: Physico-chemical properties, antioxidant capacity and application as bakery product ingredients. Malays. J. Nutr. 2013, 19, 99-110.

57. Rubel, I.A.; Pérez, E.E.; Manrique, G.D.; Genovese, D.B. Fibre enrichment of wheat bread with Jerusalem artichoke inulin: Effect on dough rheology and bread quality. Food Struct. 2014, 3, 21-29. [CrossRef]

58. Bigne, F.; Puppo, M.C.; Ferrero, C. Fibre enrichment of wheat flour with mesquite (Prosopis spp.): Effect on breadmaking performance and staling. LWT 2016, 65, 1008-1016. [CrossRef]

59. Millar, K.A.; Barry-Ryan, C.; Burke, R.; McCarthy, S.; Gallagher, E. Dough properties and baking characteristics of white bread, as affected by addition of raw, germinated and toasted pea flour. Innov. Food Sci. Emerg. Technol. 2019, 56, 102189. [CrossRef]

60. Carocho, M.; Morales, P.; Ciudad-Mulero, M.; Fernández-Ruiz, V.; Ferreira, E.; Heleno, S.; Rodrigues, P.; Barros, L.; Ferreira, I.C.F.R. Comparison of different bread types: Chemical and physical parameters. Food Chem. 2020, 310, 125954. [CrossRef] [PubMed]

61. Coda, R.; Varis, J.; Verni, M.; Rizzello, C.G.; Katina, K. Improvement of the protein quality of wheat bread through faba bean sourdough addition. LWT 2017, 82, 296-302. [CrossRef]

62. Sahin, A.W.; Zannini, E.; Coffey, A.; Arendt, E.K. Sugar reduction in bakery products: Current strategies and sourdough technology as a potential novel approach. Food Res. Int. 2019, 126, 108583. [CrossRef] [PubMed] 